Nebojša S. Marinković*

Columbia University, Department of Chemical Engineering, New York, USA
Scientific paper

ISSN 0351-9465, E-ISSN 2466-2585

UDC:620.187./.187

doi: 10.5937/ZasMat1802273M

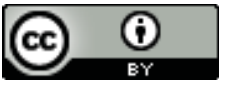

Zastita Materijala 59 (2)

$273-281$ (2018)

\title{
Optimization of in situ infrared spectro-electrochemical accessory with the aid of reflectance and electric field and calculations
}

\begin{abstract}
Optical design of the in situ infrared reflection-absorption spectroscopy (IRRAS) accessory is discussed, with a particular attention to its optimization on the base of theoretical calculations. The sensitivity of this versatile technique applicable to most mono- and polycrystalline electrodes can be greatly enhanced by carefully adjusting the angle of incidence of infrared (IR) beam and the position of the electrode. Using Fresnel equations, we show that the reflectivity and the strength of the electric field of a stratified medium are interconnected, so that the magnitude of the electric field strength can be monitored by the reflectivity of the light into the first layer, and ultimately into the IR detector. The result of calculating these effects for the three-layer system, zinc selenide crystal / aqueous solution / Pt electrode, clearly shows that the intensity of the interferogram in the spectrometer can be used to precisely adjust the angle of incidence of the IRRAS accessory: the interferogram strength is increasing by pressing the Pt electrode on the ZnSe crystal at or near the optimal incident angle and decreasing when the angle of incidence is only a few degrees away from optimal. By combining the results of the calculation of the electric field with an experiment, an optimized system for identifying and tracking various species adsorbed on the surface of the electrode or within a few micrometers from the surface in the solution due to the change in the electrochemical potential can be achieved.
\end{abstract}

Keywords: ATR, Otto configuration, IRRAS, Electric field, Fresnel equations.

\section{INTRODUCTION}

Infrared (IR) spectroscopy has found its place in analyzing surfaces of various materials, for instance in oxides on metal surfaces, corrosion products, measurement of film thickness and the analysis of the growth of metal protective layers and corrosion inhibitors. It is also an established tool for studying metal/electrolyte interface at a molecular level, as it provides identification of the species involved in adsorption/desorption and surface bonding, as well as information of their orientation, coordination, etc., and has substantially advanced our knowledge on both organic and inorganic chemical reactions on electrochemical surfaces.

${ }^{*}$ Corresponding author: Nebojša S. Marinković E-mail: marinkov@bnl.gov

Paper received: 20. 04. 2018.

Paper accepted: 03. 05. 2018.

Paper is available on the website: www.idk.org.rs/journal
When an electrochemical potential is applied at an electrode in contact with electrolyte, the molecular and ionic species in the liquid phase become organized near the surface. IR radiation penetrating to the electrode is partly absorbed by the species in the optical path, and the acquired spectrum represents a sum of absorbance of the species in the bulk of the electrolyte layer and those near the electrode, in which the latter contributes to only a fraction of a percent. Several review papers have covered aspects related to coupling IRRAS with electrochemical systems, offering various approaches to solve the main challenge associated with IR spectroelectrochemistry due to the large IR absorption by the electrolyte with respect to relatively weak signal from the sub-monolayer of the species on the electrode surface [1-6]. Greenler pioneered the application of IR reflectance spectroscopy at metal surfaces in 1960s [7-9], and Bewick expanded the application in studying electrode/electrolyte 
interface [10-13] and termed the technique Infrared reflection absorption spectroscopy (IRRAS). Various other names for fundamentally the same technique have been used in the literature, including Electrochemically modulated infrared spectroscopy (EMIRS), Subtractively normalized interfacial Fourier transform infrared spectroscopy (SNIFTIRS) and Single potential alteration infrared reflectance spectroscopy (SPAIRS), not be confused with Polarization modulation Fourier transform infrared spectroscopy (PM-FTIR) for studies of gas-phase adsorbates on metal surfaces [10-20]. Two categories of setups were offered: external and internal geometry. In external geometry the IR beam passes through a window, penetrates through the solution, reflects from the electrode surface and traverses back through the solution and the window again before reaching the detector. In the internal geometry, the window is made of high refractive index material and the angle of incidence is made such that the IR beam totally reflects from the window/solution interface. Simultaneously, an evanescent wave is generated at the interface, penetrating the rarer medium (i.e. electrolyte) and thus containing the information of the absorbing species in it, but with the electric field amplitude decaying exponentially and falling to practically zero at distances greater than $10 \mu \mathrm{m}$ from the interface. This is the basis of the Attenuated Total Reflection (ATR) which is commonly used in infrared spectroscopy. In electrochemistry, the working electrode may be deposited directly onto the window or separated by the electrolyte giving rise to Kretschmann and Otto configurations, respectively $[21,22]$. While the Kretschmann configuration offers a powerful tool for adsorbates at the metal surface as the high absorbing effect of the solution layer is avoided, it can be only studied to limited number of surfaces. In in situ IRRAS in Otto configuration the electrolyte layer is squeezed to a fraction of a micrometer by pressing the metal surface against a IR-transparent crystal, and this technique was shown to be more versatile as it is applicable to most surfaces [23]. To extract useful information on the species of interest found in the near-electrode layer, consisting of solution and adsorbed species, chemical reaction products and intermediates etc., an IR spectrum is usually acquired as the difference in absorption at two potentials. The absorbance of species unaffected by the potential difference therefore cancel out, and the resulting IR spectrum contains both positive and negative peaks due to buildup / fall off species in the double layer and adsorption / desorption of the species at the metal surface, respectively.

In the present paper we discuss the optimization of this highly useful technique, based on the theoretical calculations of the electric field that probes the metal/solution interface, together with experimental confirmation of the calculated results.

\section{RESULTS AND DISCUSSION}

Calculation of the electrical field in this work is based on the equations developed by Hansen [24]. The equations can easily be inserted into a widelyused program like Excel, or into an on-line program [25].

The refraction of light passing from one phase into another are described by Snell's Law, $n_{1} \sin \theta_{1}$ $=n_{2} \sin \theta_{2}$, where the refractive indices of the two phases $n_{1}$ and $n_{2}$ describe the ratios of the speed of light in the vacuum and in that medium, and the angles $\theta_{1}$ and $\theta_{2}$ are measured towards the surface normal. In the case of the light propagating from an optically denser into optically rarer medium, there exists a critical angle $\theta_{c}=\sin ^{-1}\left(n_{2} / n_{1}\right)$ at which the beam is refracted parallel to the interface of the two phases, i.e. $\theta_{2}=90^{\circ}$ and $\sin \theta_{2}=1$. At incidence angles larger than $\theta_{c}, \theta_{2}$ becomes imaginary and the refracted beam is reflected into the denser medium, but carries the information on the absorption of species in the rarer medium. This ATR phenomenon is utilized in the accessory for infrared spectroelectrochemistry.

\subsection{Optical setup schematic}

The schematic representation of the setup used in this study consists of a IR-transparent, high refractive index hemisphere and two first-surface gold mirrors (Figure 1 ). If the IR beam path is raised $8.9 \mathrm{~cm}(3.5$ ) from the base of the internal chamber, and the walls of the chamber are separated $21.6 \mathrm{~cm}\left(8.5^{\prime \prime}\right)$ from each other, which is a standard in today's FTIR instruments, and using the radius of the hemisphere $r$ of $1.27 \mathrm{~cm}(0.50 ")$, one can calculate the other distances based on the geometry of the setup. The distance $b$ from the surface of the folding gold mirror to the instrument's focal point $F$ is related to the distance from the folding mirror to the flat side of the hemisphere, so that: $b=(b+d+r) \sin \theta$, where $\theta$ is the angle of incidence to the hemisphere/solution boundary; similarly, the height of the flat surface of the hemisphere from the incidence beam is $(b+d+r)$ $\cos \theta$. It can be shown that the dimensions of the setup are optimal for crystal hemispheres with 
refraction index $n_{1}$ between 2 and 2.5 , because the height of the flat side of the hemisphere above the instrument focal plane leaves just enough space for the positioning of a wire grid polarizer oriented perpendicular to the beam direction at the accessory's focal point F'. A setup involving hemispheres of higher refractive index materials (Si or $\mathrm{Ge}$ ) can be achieved without polarizer, whereas the use of lower refractive index hemispheres (e.g.
$\mathrm{CaF}_{2}$ ) requires an external chamber because of very long $b$ and $h$ distances [26]. Of the materials with desirable index of refraction, including KRS-5 (Thallium bromoiodide), ZnS and ZnSe, the latter has low toxicity, low solubility in most dilute acids and bases and reasonable hardness, besides a wide useful transmission in IR, thus allowing investigation of a broad range of spectral vibrations.

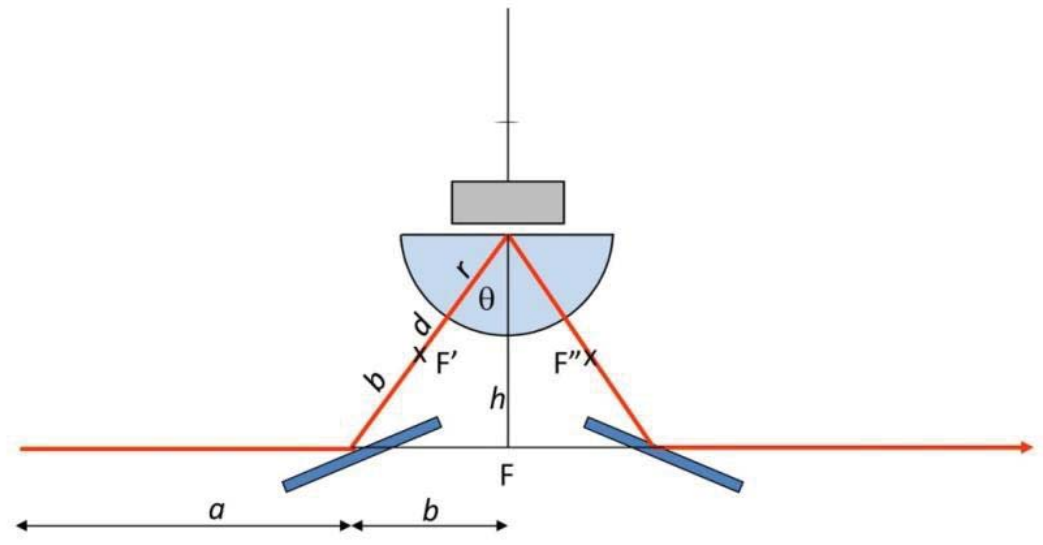

Figure 1. Schematic representation of the attachment for in situ IRRAS in Otto-configuration. FTIR instrument delivers the IR beam focused into the focal point $F$; the focal point is moved by the accessory's first folding mirror to $F$ ' in front of the curvature of the ATR hemisphere with the radius $r$; the light entering the hemisphere is collimated by the curvature and strikes the ATR-electrolyte interface at the precise angle of incidence $\theta$; upon total reflection from the interface, the IR light refocuses by the hemisphere curvature into the focal point F", and is directed towards IR detector by the second folding mirror. The distances are as follows: (a) distance from the internal chamber wall to the folding mirror, (b) distance from the folding mirror to the focal point, (d) distance from the focal point to the curvature of the hemisphere, ( $h$ ) distance from the instrument's focal point $F$ to the flat surface of the hemisphere

Slika 1. Šematski prikaz optičkog dodatka za in situ IRRAS u Otto konfiguraciji. FTIR Instrument usmerava infracrveni zrak u žižnu tačku F; prvo usmeravajuće ogledalo pomera fokusnu tačku u F' neposredno ispred krivine ATR hemisfere radijusa r; svetlost koja ulazi u hemisferu je kollimirana usled krivine hemisfere i pada na medjusloj ATR-elektrolit pod preciznim upadnim uglom $\theta$; nakon totalne refleksije od medjusloja, krivina ATR hemisfere refokusira IC zrak u žižnu tačku F" i dalje prema IC detektoru nakon odbijanja od drugog usmeravajućeg ogledala. Rastojanja su sledeća: (a) rastojanje od unutrašnjeg zida komore do ogledala, (b) rastojanje od ogledala do žižne tačke, (d) rastojanje od žižne tačke do krivine hemisfere, (h) rastojanje od žižne tačke $F$ instrumenta do ravne površine hemisphere

\subsection{Penetration depth calculation}

The penetration depth $\delta_{p}$ is the distance at which the intensity of the evanescent wave falls to $\mathrm{e}^{-1}(-37 \%)$ of its value at the surface, and is typically between 0.5 and $2 \mu \mathrm{m}$, depending on the wavelength of the radiation $\lambda$ and the refraction indices of the optically denser and rarer media, $n_{1}$ and $n_{2}$ :

$$
\delta_{p}=\lambda /\left[2 \pi\left(n_{1}^{2} \sin ^{2} \theta-n_{2}^{2}\right)^{1 / 2}\right]
$$

The equation (1) can be used if the both media are either non-absorbing or weakly-absorbing, as in the case for IR-transparent hemisphere in contact with aqueous electrolyte. In general case, the refraction index is a complex number, $\tilde{n}=n+i k$, where the imaginary part $k$ (extinction coefficient) describes optical losses in the medium. For $\mathrm{ZnSe} /$ water interface in mid-IR range, the refractive index $n_{1}$ of ZnSe contains only the real part $\left(k_{1}=0\right)$ and the penetration depth increases linearly with $\lambda$ except in the region where the extinction coefficient of water $k_{2}$ passes through a maximum due to the $\mathrm{OH}$ stretching and bending mode occurring around 3.3 and $6.5 \mu \mathrm{m}$, respectively, producing the sshaped change in the real part of the refractive index $n_{2}$ (Figure 2). 


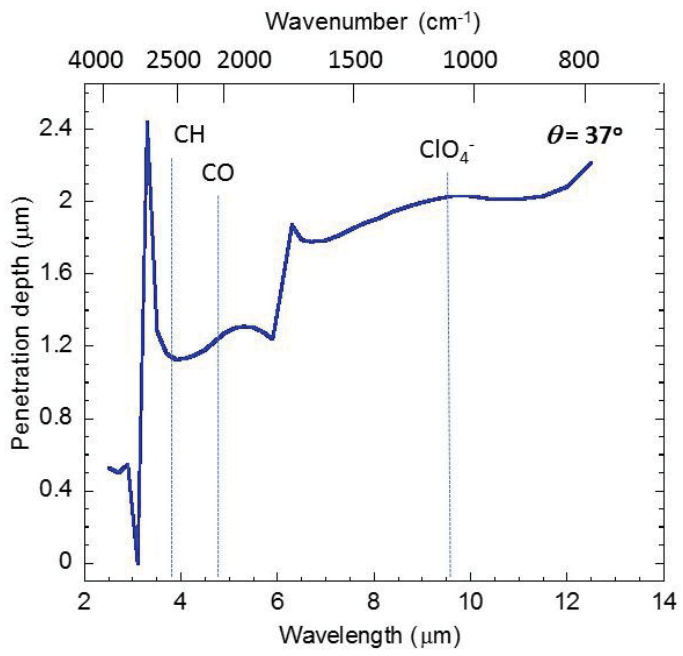

Figure 2. Penetration depth for ZnSe / water interface at the incidence angle of $\theta_{1}=37^{\circ}$

Slika 2. Dubina penetracije za medjusloj ZnSe / voda pri upadnom uglu od $\theta_{1}=37^{\circ}$

\subsection{Electric field and reflectivity calculations}

The optical properties of a phase can be completely characterized using the dimensionless magnetic permeability relative to free space $\mu$ and the complex index of refraction. Most materials including water and Pt have magnetic permeability very close to unity [27], so that the exact formulas given in Hansen [24] can be somewhat simplified. For the calculations presented below, we used the three-layer system comprised of zinc selenide/water/platinum phases, where the thicknesses of the first and third phases ( $\mathrm{ZnSe}$ and $\mathrm{Pt}$ ) are assumed infinite, and the thickness of the second (water) layer is $h$ in the direction of propagation of the IR light (Figure 3). The optical constants for ZnSe, water and platinum are available in the literature [28], and their interpolated values for selected wavelengths in mid-IR range are given in Table 1.

Table 1. Refractive indices for zinc selenide, water and platinum for the selected wavelengths $\lambda[28]$

Tabela 1. Indeksi refrakcije za cink selenid, vodu $i$ platinu za odredjene talasne dužine IC svetlosti $\lambda$.

\begin{tabular}{|c|c|c|c|c|c|}
\hline & ZnSe & \multicolumn{1}{|c|}{$\mathrm{H}_{2} \mathrm{O}$} & $\mathrm{Pt}$ & \\
\hline$\lambda(\mu \mathrm{m})$ & $\mathrm{n}$ & $\mathrm{n}$ & $\mathrm{k}$ & $\mathrm{n}$ & $\mathrm{K}$ \\
\hline 2 & 2.431 & 1.341 & 0.00460 & 5.292 & 6.683 \\
\hline 3.3 & 2.436 & 1.450 & 0.0368 & 3.047 & 11.93 \\
\hline 5 & 2.415 & 1.325 & 0.00124 & 4.106 & 19.84 \\
\hline 8 & 2.406 & 1.291 & 0.0343 & 8.374 & 31.66 \\
\hline 10 & 2.399 & 1.218 & 0.0508 & 11.93 & 38.40 \\
\hline 12 & 2.388 & 1.111 & 0.199 & 15.74 & 44.35 \\
\hline
\end{tabular}

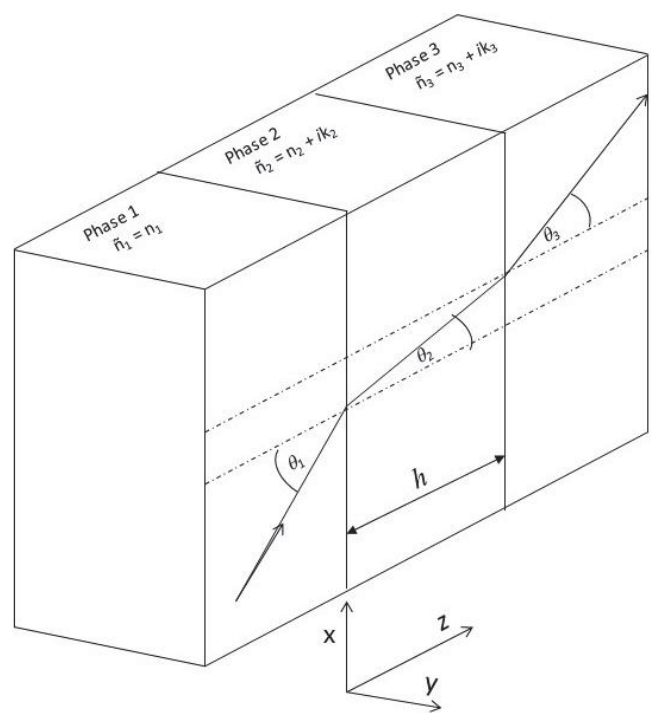

Figure 3. General schematic presentation of 3phase stratified medium; the first phase is assumed non-absorbing for the incident plane-coherent electromagnetic radiation so that $\tilde{n}_{1}=n_{1}$, and the other two absorbing phases are characterized by complex indices of refraction $\tilde{n}_{2}$ and $\tilde{n}_{3}$. The thickness of the second phase is $h$ along the propagation of the EM radiation (z coordinate), and the incidence angles at the phase boundary are $\theta_{i}$

Slika 3. Šematski prikaz troslojnog optičkog medijuma; za prvu fazu se uzima da ne-apsorbuje upadni elektromagnetski zrak koherentan u ravni, pa je $\tilde{n}_{1}=n_{1}$, dok su druge dve faze apsorbujuće sa kompleksnim indeksom refrakcije $\tilde{n}_{2}$ and $\tilde{n}_{3}$.

Debljina druge faze je $h$ u pravcu prostiranja EM zračenja (z koordinata), a upadni uglovi na granicama faze su $\theta_{i}$

At the interface of any two phases, the polarization state of both reflected and transmitted lights change. These effects are treated by Fresnel equations separately for the two components of the light, i.e. the component polarized parallel to the plane containing the incident, reflected and refracted rays ( $p$-polarized light, or transversemagnetic), and the component perpendicular to the above plane (s-polarized light, or transverseelectric). The absorption of a phase is given as the energy dissipated in the unit volume of the phase per unit time, and defined as the product of conductivity $\sigma$ and the mean square electric field (MSEF), <Ez> ${ }^{2}$. The conductivity $\sigma=n k v / \mu$ is related to the optical properties of the absorbing phase and the frequency of the light $v$, and the magnitude of MSEF depends on the refractive indices of all media, thickness of the second layer and the angle of incidence of the radiation into the first medium $\theta_{1}$.

For metal particles greater than ca. $2 \mathrm{~nm}$, metal surface selection rule predicts that the infrared absorption bands with the oscillating dipole 
moment parallel to the surface, or perpendicular to the plane of incidence (s-polarized light) are absent from the spectra of molecules adsorbed on the metal, because the vectors before and after the reflection of the light at the surface almost completely cancel out. Opposite is true for the $p$ polarized where the vectors before and after the reflection add together, thus almost doubling the resulting magnitude. Hence only $p$-polarized light interacts with the particles adsorbed on the metal surface; furthermore, particles will be induced to vibration only if they possess the component of the dipole moment perpendicular to the surface. This is called surface selection rule, and because of it the equations for s-polarization will not be considered here. It should be noted that the surface selection rule does not apply to the randomly-oriented species in the solution layer, which are excited with both $s$ - and $p$ - polarized light.

From Fresnel equations, it can be shown that the MSEF for $p$-polarized light for tri-phase system that is established at the metal-solution phaseboundary depends on the fraction of the light that is transmitted through the solution layer (Eq. 2):

$$
<E_{p 3 z}^{2}>=1 / 2\left|\frac{n_{1} t_{E p} \sin \theta_{1}}{\tilde{n}_{3}}\right|^{2}\left(E_{p 1}{ }^{o t}\right)^{2}
$$

where $E_{p 1}{ }^{\text {ot }}$ represents the electric field of the $p$ component of the plane wave at the first phase at the time $\mathrm{t}=0$. Other factors are as follows:

$$
\begin{gathered}
t_{E p}=\frac{n_{1} t_{p 12} t_{p 23} e^{i \beta}}{\tilde{n}_{3}\left(1+r_{p 12} r_{p 23} e^{2 i \beta}\right)} \\
\beta=2 \pi(h / \lambda)\left(\tilde{n}_{2}^{2}-n_{1}^{2} \sin ^{2} \theta_{1}\right)^{1 / 2} \\
t_{p j k}=\frac{2 \tilde{n}_{k}^{2}\left(\tilde{n}_{j}^{2}-n_{1}^{2} \sin ^{2} \theta_{1}\right)^{1 / 2}}{\tilde{n}_{k}^{2}\left(\tilde{n}_{j}^{2}-n_{1}^{2} \sin ^{2} \theta_{1}\right)^{1 / 2}+\tilde{n}_{j}^{2}\left(\tilde{n}_{k}^{2}-n_{1}^{2} \sin ^{2} \theta_{1}\right)^{1 / 2}} \\
r_{p j k}=\frac{\tilde{n}_{k}^{2}\left(\tilde{n}_{j}^{2}-n_{1}^{2} \sin ^{2} \theta_{1}\right)^{1 / 2}-\tilde{n}_{j}^{2}\left(\tilde{n}_{k}^{2}-n_{1}^{2} \sin ^{2} \theta_{1}\right)^{1 / 2}}{\tilde{n}_{k}^{2}\left(\tilde{n}_{j}^{2}-n_{1}^{2} \sin ^{2} \theta_{1}\right)^{1 / 2}+\tilde{n}_{j}^{2}\left(\tilde{n}_{k}^{2}-n_{1}^{2} \sin ^{2} \theta_{1}\right)^{1 / 2}}
\end{gathered}
$$

where Fresnel coefficients $t_{p j k}$ and $r_{p j k}$ represent the $p$-polarized parts of the plane wave that are transmitted and reflected into the $j-k$ phase boundary (j,k $=1,2,3)$, and $\beta$ depends on the thickness of the second phase $h$ and wavelength $\lambda$ of the radiation.

The reflectance into the phase 1 can be calculated from the reflectivity coefficients in respective layers (Eq. 3d), using Eq. 4:

$$
R_{p}=\left|\frac{r_{p 12}+r_{p 23} e^{2 i \beta}}{1+r_{p 12} r_{p 23} e^{2 i \beta}}\right|^{2}
$$

Because the absolute value of $E_{p 1}{ }^{\text {ot }}$ in Eq. 2 is generally unknown, we have calculated the relative magnitude of the electric field as the ratio of the MSEF established at the metal/water boundary to that at the ZnSe/water interface for $p$-polarized IR light of the wavelength of $\lambda=4.9 \mu \mathrm{m}\left(2040 \mathrm{~cm}^{-1}\right)$ as a function of angle of incidence for different thicknesses of the water layer.

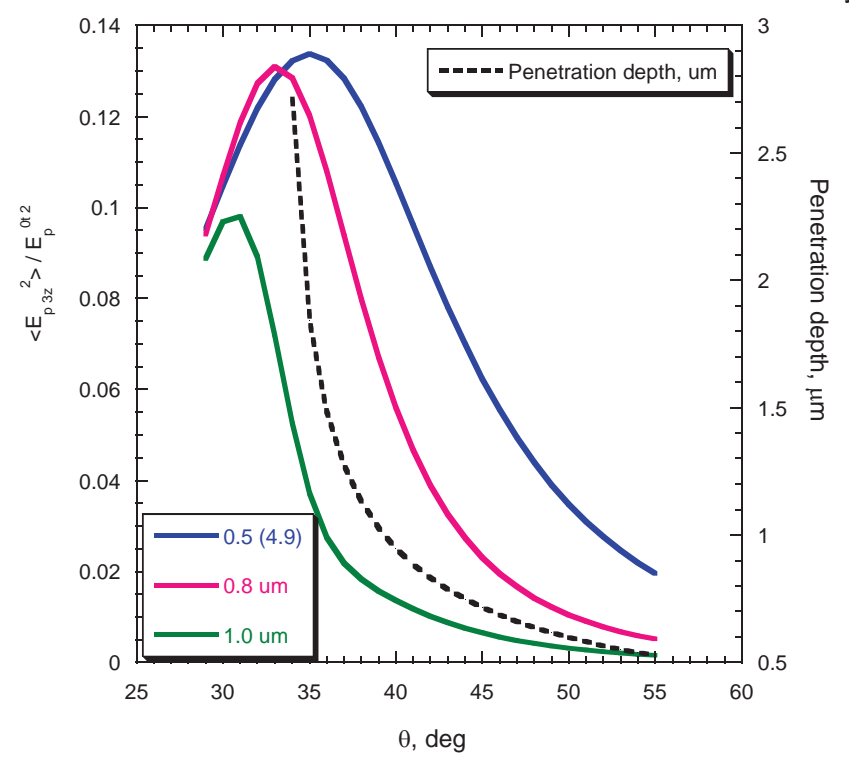

Figure 4. Relative magnitude of the electric field for p-polarized light of the wavelength of $4.9 \mu \mathrm{m}\left(2040 \mathrm{~cm}^{-1}\right)$ as a function of the angle of incidence into the first phase $\theta_{1}$ for the solution thicknesses of $0.5,0.8$ and $1.0 \mu \mathrm{m}$ (blue, red and green lines, respectively), and the penetration depth into water (dashed) from ZnSe / water interface of the $\mathrm{ZnSe} / \mathrm{H}_{2} \mathrm{O} / \mathrm{Pt}$ tri-phase system

Slika 4. Relativna jačina električnog polja za p-polarizovanu svetlost talasne dužine od $4.9 \mu \mathrm{m}\left(2040 \mathrm{~cm}^{-1}\right) \mathrm{kao}$ funkcija upadnog ugla u prvu fazu $\theta_{1}$ za debljine rastvora 0.5, 0.8 i $1.0 \mu \mathrm{m}$ (plava, crvena i zelena kriva, redom), i dubina penetracije (isprekidana linija) u sloj vode od medjufaze ZnSe / voda za trofazni sistem $\mathrm{ZnSe} / \mathrm{H} \mathrm{O}_{2} \mathrm{O} / \mathrm{Pt}$ 
The results of the calculations are summarized in Figure 4. As expected, as the solution thickness increases the relative magnitude decreases in intensity; furthermore, the maximum of the curves shifts to lower incidence angles. Simultaneously, the penetration depth rises by two orders of magnitude as the angle of incidence is changed from $55^{\circ}$ to $37^{\circ}$, and continues to rise to infinity at the critical angle of $\theta_{c} \approx 33^{\circ}$ (for this wavelength of the incoming radiation). Because the real part of refractive index of water can be anywhere between 1.11 and 1.45 (Table 1), the optimal angle of incidence for the in situ IRRAS setup should not be smaller than $32^{\circ}$, as the incidence angle that is equal to the critical angle produces nonphysical absorbance peaks in the spectra, but it should not be larger than $37^{\circ}$, as a too large angle of incidence reduces both MSEF at the metal/water boundary and the penetration depth. Furthermore, to maximize the interaction of the MSEF with the species at the surface, it appears that the optimal solution thickness should be less than $1 \mu \mathrm{m}$.

\subsection{Optimization of the accessory}

The optimal angle of incidence may be difficult to obtain unless the IR light is collimated. Today's FTIR spectrometers usually have the IR beam focused into a ca. 3-mm diameter spot near the center of the internal chamber, with the distance from the focusing mirrors of $6 "(152.4 \mathrm{~mm})$, so that the angle of incidence at the focal point can vary as

a)

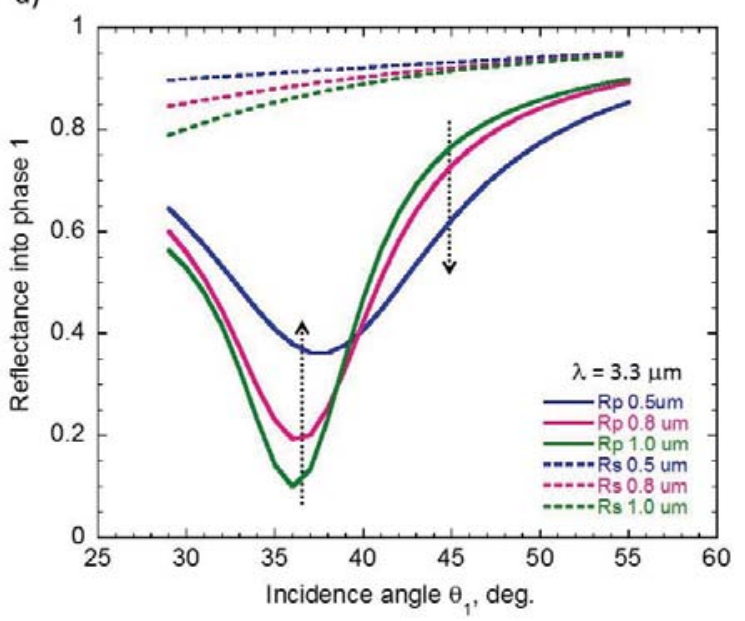

much as $\pm 6^{\circ}$. This obstacle can be rectified using a hemisphere (or hemicylinder) as the ATR element: if the focal point is placed before the curved surface at the distance $d=r /(n-1)$, where $r$ is the radius of the curvature, the hemisphere acts as a lens collimating the beam inside the crystal [29]. The consequence is a well-defined angle of incidence at the flat side of the hemisphere.

It is obvious that both the penetration depth and the electric filed strength should be optimized so that the IR beam can penetrate the thickness of the solution layer, and to maximize the interaction of the established MSEF at the metal/solution boundary with the dipole moment of the adsorbed surfaces. However, it is not at all obvious how this could be achieved without tedious, precise adjustments of the angle of incidence and all distances of the setup in Fig. 1 and observing the acquired spectra. We show here that there is a faster and easier way that involves observing the intensity of the interferogram strength. Using the equation for the reflectance into the first phase (and ultimately into the IR detector), Eq. 4, one can accurately adjust the optics of the accessory. Figure 5 shows the calculated reflectance into the first phase (ZnSe) from the ZnSe/water/Pt tri-layer system as a function of angle of incidence for both polarizations and different thicknesses of water layer.

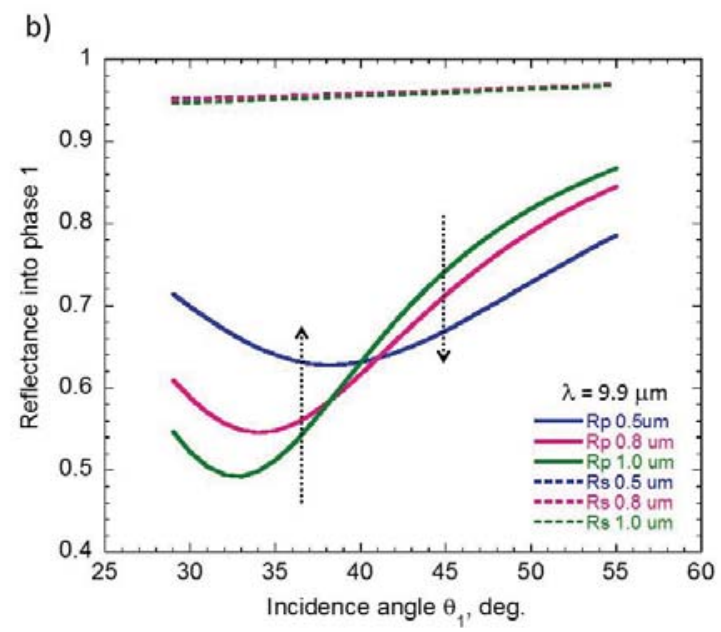

Figure 5. Calculated reflectance into the $\mathrm{ZnSe}$ phase from $\mathrm{Pt} / \mathrm{H}_{2} \mathrm{O}$ interface of the $\mathrm{ZnSe} / \mathrm{H}_{2} \mathrm{O} / \mathrm{Pt}$ triphase system for s- (dashed lines) and p-polarized light (full lines) and thicknesses of water layer of 0.5, 0.8 and $1.0 \mu \mathrm{m}$ (blue, red and green lines), and the incident radiation of $1010 \mathrm{~cm}^{-1}$ (a) and $3030 \mathrm{~cm}^{-1}$ (b).

Slika 5. Proračun refleksije u fazu ZnSe od medjusloja Pt / $\mathrm{H}_{2} \mathrm{O}$ za trofazni sistem $\mathrm{ZnSe} / \mathrm{H}_{2} \mathrm{O} / \mathrm{Pt}$ za s(isprekidane linije) i p-polarizovanu svetlost (pune linije) i debljine sloja vode od 0,5, 0,8 i 1,0 $\mu$ m (plave, crvene i zelene linije), i za upadno zračenje od $1010 \mathrm{~cm}^{-1}$ (a) i $3030 \mathrm{~cm}^{-1}$ (b) 
From the Figure 5 it follows that the reflectance of $s$-polarized light changes in intensity only slightly over all angles of incidence. Contrary to that, the reflectance of $p$-polarization changes dramatically, especially at lower wavelengths of the IR light, passing through a minimum between 33 and $37^{\circ}$. However, by pressing the electrode against ZnSe crystal, and thus squeezing the water layer from 1.0 to $0.5 \mu \mathrm{m}$ produces as much as four-fold change in the reflectance. Furthermore, the behavior of the curves for different thicknesses of water layer shows how to precisely optimize the angle of incidence: at angles of incidence much higher than optimized, pressing the electrode against the ZnSe crystal causes the decrease in reflectance in the first layer and into the IR detector of the spectrometer; at angles of incidence close to, but still above the optimum angle the reflectance stays almost constant regardless of the thickness of water layer; and finally, at the optimized angle, the reflectance measured as the centerburst of the interferogram strength of the spectrometer, should show a remarkable increase.

While the dramatic change in reflectance during the optimization of the angle of incidence can be best observed using $p$-polarized light, the increase in the reflectance upon pressing the electrode against the ATR crystal can be also followed without polarizer. Summing the calculated reflectance for $s$ - and $p$-polarized components, we show that the total reflectance into the first layer from ZnSe/air interface (i.e. without solution and Pt) at the angle of incidence of $37^{\circ}$ should be about $97 \%$ of the intensity of the incidence light. The minor drop in the total reflectivity is the invariable consequence of the reflection from any surface, including the best IR mirrors like gold and silver [30, 31]. Adding water onto the ZnSe ATR element causes the decrease in the total reflectance to about $60 \%$. Lastly, pressing the electrode against the $\mathrm{ZnSe}$ and creating the water layer thickness of ca. $0.5 \mu \mathrm{m}$ causes the increase in reflectance, to about $80 \%$ of the incidence light. These changes in reflectivity can be followed by observing the interferogram strength. However, it should be noted that the centerburst of the interferogram represents the sum of all IR wavelengths, and the effect of the change in reflectance is different for various wavelengths, as seen in Figs. $5 a$ and $5 b$. Nevertheless, the above reflectivity calculations reasonably agree with the intensity of the centerburst of the interferogram strengths we observed experimentally.

\section{CONCLUSIONS}

Precise optimization of the in-situ IR reflection accessory for spectroelectrochemical system is tedious, often consisting of trial-and-error in measuring absorbances of a control experiment after an incidence angle is set. We have shown that the theoretical predictions of the propagation of IR light in stratified media can be successfully applied in optimization of the system. The highest electrical field strength that excites vibration of the species adsorbed at the metal surface can be predicted by the calculations, showing that it passes through a maximum at an incidence angle that is only a few degrees larger than the critical angle of the ATR crystal/solution interface. Incidentally, pressing the electrode against the surface causes the intense change in the reflection, and the latter phenomenon can be used for precise adjustment of the setup. The optimized system is instrumental for identification of species in the near-surface layer and their behavior during the potential excursion.

\section{REFERENCES}

[1] A. Bewick (1986) Molecular Structure and Orientation in the Electrode/Electrolyte Solution Interface - In Situ IR Spectroscopy in A. Fernando Silva (Ed.) Trends in Interfacial Electrochemistry. Springer Netherlands, 179, 331-358.

[2] A. Antonio Berna, A. Rodes, J.M. Feliu (2007) Insitu FTIR Studies on the Acid-Base Equilibria of Adsorbed Species on Well-Defined Metal Electrode Surfaces. in S.-G. Sun, P.A. Christensen, A. Wieckowski (Eds.) In-situ Spectroscopic Studies of Adsorption at the Electrode and Electrocatalysis, Elsevier, 1-32.

[3] J.-M. Leger, F. Hahn (2007) Contribution of In-situ Infrared Reflectance Spectroscopy in the Study of Nanostructured Fuel Cell Electrodes in S.-G. Sun, P.A. Christensen, A. Wieckowski (Eds.) In-situ Spectroscopic Studies of Adsorption at the Electrode and Electrocatalysis, Elsevier, 63-98.

[4] C. Korzeniewski (2007) Recent Advances in in-situ Infrared Spectroscopy and Applications in Singlecrystal Electrochemistry and Electrocatalysis, S.-G. Sun, P.A. Christensen, A. Wieckowski (Eds.) In-situ Spectroscopic Studies of Adsorption at the Electrode and Electrocatalysis, Elsevier, 179-208.

[5] M. Osawa (2009) In-situ Surface-enhanced Infrared Spectroscopy of the Electrode/Solution Interface in R.C. Alkire, D.M. Kolb, J. Lipkowski, P.N. Ross (Eds.) Advances in Electrochemical Science and Engineering. Diffraction and Spectroscopic Methods in Electroelectrochemistry, John Wiley \& Sons, 9, 269-314. 
[6] V. Zamlynny, J. Lipkowski (2009) Quantitative SNIFTIRS and PM IRRAS of Organic Molecules at Electrode Surfaces in R.C. Alkire, D.M. Kolb, J. Lipkowski, P.N. Ross (Eds.) Advances in Electrochemical Science and Engineering. Diffraction and Spectroscopic Methods in Electroelectrochemistry, John Wiley \& Sons, 9, 315376.

[7] R.G. Greenler (1966) Infrared Study of Adsorbed Molecules on Metal Surfaces by Reflection Techniques, J. Chem. Phys., 44, 310-315.

[8] R.G. Greenler (1969) Reflection Method for Obtaining the Infrared Spectrum of a Thin Layer on a Metal Surface, J. Chem. Phys., 50, 1963-1968.

[9] R. G. Greenler (1975) Design of a reflectionabsorption experiment for studying the IR spectrum of molecules adsorbed on a metal surface, J. Vac. Sci. Technol., 12, 1410-1417.

[10] A. Bewick, K. Kunimatsu, B.S. Pons, J.W. Russell (1984) Electrochemically modulated infrared spectroscopy (EMIRS) experimental details, J. Electroanal. Chem., 160, 47-61.

[11] T. Davidson, B.S. Pons, A. Bewick, P.P. Schmidt (1981) Vibrational spectroscopy of the electrode/electrolyte interface. Use of Fourier transform infrared spectroscopy, J. Electroanal. Chem., 125, 237-241.

[12] S. Pons, T. Davidson, A. Bewick (1983) Vibrational spectroscopy of the electrode-solution interface. 2. Use of Fourier transform spectroscopy for recording infrared spectra of radical ion intermediates, J. Am. Chem. Soc., 105, 1802-1805.

[13] J.W. Russel, J. Overend, K. Scanlon, M. Severson, A. Bewick (1982) Infrared spectrum of carbon monoxide on a platinum electrode in acidic solution, J. Phys. Chem., 86, 3066-3068.

[14] S. Pons (1983) The use of Fourier transform infrared spectroscopy for in situ recording of species in the electrode-electrolyte solution interphase, J. Electroanal. Chem., 150, 495-504.

[15] D.S. Corrigan, L.W.H. Leung, M.J. Weaver (1987) Single potential-alteration surface infrared spectroscopy: examination of absorbed species involved in irreversible electrode reactions, Anal. Chem., 59, 2252-2256.

[16] K.W. Hipps, G.A. Crosby (1979) Applications of the photoelastic modulator to polarization spectroscopy, J. Phys. Chem., 83, 555-562.

[17] W.G. Golden, K. Kunimatsu, H. Seki (1984) Application of polarization-modulated Fourier transform infrared reflection-absorption spectroscopy to the study of carbon monoxide adsorption and oxidation of a smooth platinum electrode, J. Phys. Chem., 88, 1275-1277.
[18] H. Seki, K. Kunimatsu, W.G. Golden (1985) A thinlayer electrochemical cell for infrared spectroscopic measurements of the electrode/electrolyte interface, Appl. Spectrosc., 39, 437-443.

[19] W.G. Golden, D.D. Saperstein, M.W. Severson, J. Overend (1984) Infrared reflection-absorption spectroscopy of surface species: a comparison of Fourier transform and dispersion methods, J. Phys. Chem., 88, 574-580.

[20] T. Iwasita, F.C. Nart (1997) In situ infrared spectroscopy at electrochemical interfaces, Prog. Surf. Sci., 55, 271-340.

[21] A. Otto (1968) A new method for exciting nonradioactive surface plasma oscillations, Phys. Stat. Sol., 26, K99-K101.

[22] E. Kretschmann, H. Reather (1968) Radiative decay of non-radiative surface plasmons excited by light, Z. Naturf., 23, 2135-2136

[23] P.W. Faguy, N.S. Marinkovic (1996) Design and Performance of a New Infrared Reflection Accessory for Spectroelectrochemical Studies, Appl. Spectrosc., 50, 394-400.

[24] P.W. Hansen (1968) Electric Fields Produced by the Propagation of Plane Coherent Electromagnetic Radiation in a Stratified Medium, J. Opt. Soc. Am., $58,380-390$.

[25] We used on-line program Wolfram Alpha: www.wolframalpha.com

[26] M. Li, N.S. Marinkovic (2013) In situ Infrared Spectroelectrochemistry: Principles and Applications in D. Cozzolino (Ed.) Infrared Spectroscopy: Theory, Developments and Applications, Nova Science Publishers, 307-332.

[27] Permeability in Wikipedia: https://en.wikipedia.org/wiki/Permeability_(electrom agnetism)

[28] Refractive indexes for $\mathrm{ZnSe}, \mathrm{H}_{2} \mathrm{O}$ and Pt are given in:

https://refractiveindex.info/?shelf=main\&book=ZnSe \&page=Querry,

http://refractiveindex.info/?shelf=main \&book=H2O\& page $=$ Hale

https://refractiveindex.info/?shelf=main\&book=Pt\&p age $=$ Windt

[29] J. Fahrenport (1961) Attenuated total reflection: A new principle for the production of useful infrared reflection spectra of organic compounds, Spectrochim. Acta, 17, 698-709.

[30] N.J. Harrick (1967) Internal Reflection Spectroscopy, John Wiley \& Sons, New York, 1-327.

[31] Reflectivity of first-surface mirrors are given in: https://www.edmundoptics.com/optics/opticalmirrors/flat-mirrors/First-Surface-Mirrors/ 


\section{IZVOD}

\section{OPTIMIZACIJA OPTICKOG DODATKA ZA IN SITUINFRACRVENU SPEKTRO- ELEKTROHEMIJU POMOĆU PRORAČUNA REFLEKTIVNOSTI I ELEKTRIČNOG POLJA}

Razmatramo optički dizajn dodatka za in situ infracrvenu reflekciono-absorpcionu spektroskopiju (IRRAS), sa posebnom pažnjom na njegovu optimizaciju na osnovu teorijskih proračuna. Osetljivost ove svestrane tehnike primenljive na većinu mono- i polikristalnih elektroda se može značajno povećati pažljivim podešavanjem upadnog ugla infracrveng (IC) zraka i pozicije površine elektrode. Pomoću Frenelovih jednačina pokazali smo da su reflektivnost i jačina električnog polja višeslojnog optičkog sistema medjusobno povezani, tako da se jačina električnog polja može pratiti pomoću refleksije svetlosti u prvi sloj, odnosno u IC detektoru. Rezultat izračunavanja ovih efekata za troslojni sistem, kristal cink selenida / vodeni rastvor / Pt elektroda, pokazuje da se jačina interferograma na infracrvenom spektrometru može uspešno koristiti za precizno podešavanje upadnog ugla dodatka za IRRAS: intenzitet interferograma se povećava pritiskanjem Pt elektrode na kristal ZnSe u blizini optimalnog upadnog ugla svetlosti, a smanjuje kada je upadni ugao svega nekoliko stepeni dalje od optimalnog. Kombinovanjem rezultata proračuna električnog polja sa eksperimentom može se dostići optimizovan sistem za identifikaciju i praćenje raznih vrsta čestica adsorbovanih na površini elektrode ili unutar nekoliko mikrometara od površine u rastvoru, usled promene elektrohemijskog potenicjala.

KIjučne reči: ATR, Oto konfiguracija, IRRAS, električno polje, Frenelove jednačine.

Naučni rad

Rad primljen: 20. 04 .2018.

Rad prihvaćen: 03. 05. 2018.

Rad je dostupan na sajtu: www.idk.org.rs/casopis

(c) 2018 Authors. Published by Engineering Society for Corrosion. This article is an open access article distributed under the terms and conditions of the Creative Commons Attribution 4.0 International license (https://creativecommons.org/licenses/by/4.0/) 